\title{
Sistem Pemberian Air secara Rotasi Daerah Irigasi Kaiti Samo di Kabupaten Rokan Hulu
}

\author{
Anggraini Lenry Rahman ${ }^{1}$, Manyuk Fauzi ${ }^{2}$, Bambang Sujatmoko ${ }^{3}$ \\ 1,2,3 Program Studi S1 Teknik Sipil, Fakultas Teknik, Universitas Riau \\ Kampus Bina Widya Jl. HR Soebrantas KM 12,5 Pekanbaru, Kode Pos 28293 \\ Email: anggraini.lenryrahman@student.unri.ac.id,manyuk.fauzi@unri.ac.id, b.sujatmoko@eng.unri.ac.id
}

\begin{abstract}
ABSTRAK
Daerah irigasi Kaiti Samo Kabupaten Rokan Hulu memiliki luas lahan irigasi 1.594 Ha. Ketersediaan debit bendung yang semakin menurun dan kebutuhan air pertanian yang semakin meningkat, sehingga perlu diatur sistem pemberian dan pengaturan air secara optimal. Rencana tata tanam dengan meningkatkan intensitas tanam menggunakan dua sistem, yaitu pemberian air dengan luasan eksisting dan penggolongan. Pengaturan air dilakukan dengan menggunakan sistem rotasi. Hasil analisis neraca air didapat bahwa terjadi kekurangan air lebih banyak ketika menggunakan luasan eksisting untuk menghitung kebutuhan air irigasi dibandingkan jika menggunakan luasan secara golongan. Persentase pemanfaatan rotasi dan penggolongan terhadap debit ketersediaan didapatkan hasil bahwa rotasi mengurangi jumlah kejadian defisit yang masih ada ketika dilakukan penggolongan, tetapi rotasi tidak menghilangkan seluruh kejadian defisit tersebut. Persentase peningkatan volume terbesar terjadi pada daerah irigasi Kaiti Samo untuk pola tanam padi-padi-padi pada bulan Juli periode I volume persentase golongan terhadap ketersediaan sebesar $-6 \%$ setelah di rotasi persentase meningkat $35 \%$ menjadi $29 \%$.
\end{abstract}

Kata kunci : irigasi, luasan eksisting, luasan golongan, sistem rotasi, neraca air.

\begin{abstract}
Kaiti Samo irrigations area of Rokan Hulu Regency has an irrigated land area of $1.594 \mathrm{Ha}$. Availability of weir debris is decreasing and agricultural water needs are increase, so it is necessary to regulate the system of giving and regulating water optimally. Planting plan by increasing cropping intensity using two systems, such as water supply with existing area and classification. Water management is carried out by fulfilling irrigation water needs and the availability of water using a rotation system. The water balance is found that there is a lack of more water when using the existing area to calculate irrigation water requirements compared to using the area area. The percentage of rotational utilization and classification of availability discharges shows that rotation reduces the number of deficit events that still exist when the analysis is classified, but the rotation does not eliminate all of the deficit events. The largest percentage increase in volume occurred in the Kaiti Samo irrigation area for paddy-paddy-paddy cropping patterns in July, the volume of group percentages to availability was -6\% after the percentage rotation increased $35 \%$ to $29 \%$.
\end{abstract}

Keywords: Irrigation, existing area system, classification system, rotation system, water balance.

\section{PENDAHULUAN}

Air irigasi bersumber dari waduk, sungai, dan air tanah. Cara untuk meningkatkan produksi pangan khususnya padi dengan tersedianya air irigasi di sawah sesuai kebutuhan. Besarnya kebutuhan air irigasi sesuai pada keadaan dan cara pengolahan lahan. Bila besarnya kebutuhan air irigasi diketahui maka dapat diprediksi pada waktu tertentu, kapan ketersediaan air dapat memenuhi dan tidak dapat memenuhi kebutuhan air irigasi sebesar yang dibutuhkan. Bila besarnya ketersediaan air tidak dapat memenuhi besarnya kebutuhan air irigasi maka harus dicari solusinya untuk dapat memenuhi kebutuhan air tersebut.

Cara untuk mengatasi masalah ketersediaan air tidak dapat memenuhi kebutuhan air irigasi dapat dilakukan dengan perbaikan jaringan irigasi. Perbaikan jaringan irigasi ini membutuhkan dana yang besar dan waktu pekerjaan yang lama. Salah satu cara lain yang dapat dilakukan di lapangan yaitu dengan membuat pola tanam sesuai dengan kondisi dan keadaan daerah irigasi tersebut, sehingga besarnya ketersediaan air di daerah irigasi dapat 
memenuhi kebutuhan air irigasi pada daerah tersebut. Jadwal pembagian air irigasi harus berdasarkan pola tanam yang cocok dengan lingkungan alam di wilayah tersebut agar menghasilkan penggunaan air dan lahan yang efektif serta menguntungkan bagi petani.

Kabupaten yang menjadi lumbung beras di Provinsi Riau adalah Kabupaten Rokan Hulu. Banyak wilayah di Kabupaten Rokan Hulu ini yang dijadikan untuk lahan pertanian atau daerah irigasi. Daerah irigasi Kaiti Samo yang terletak di Desa Kaiti, Kecamatan Rambah merupakan salah satu daerah yang dijadikan lahan pertanian. Berdasarkan Rencana Kerja Pemerintah Daerah Kabupaten Rohul Tahun 2018, luas jaringan irigasi tahun 2017 DI Kaiti Samo sekitar 1.594 ha, tetapi belum memberikan hasil pertanian dan keuntungan yang besar bagi petani. Faktor penyebab hal tersebut adalah :

1. Lahan pertanian yang dimanfaatkan (Optimal Potensial) adalah lebih kurang 700 ha, sehingga banyak sekali lahan potensial yang tidak dimanfaatkan untuk lahan pertanian.

2. Pengolahan lahan pertanian yang dilakukan oleh petani setahun dua kali dengan pola tanam PadiPadi-Bera. Sedangkan kondisi awal perencanaan oleh pemerintah daerah irigasi ini memiliki masa tanam tiga kali dalam setahun (Padi-PadiPalawija). Pada musim tanam ketiga terjadi kekurangan air pada daerah ini. Untuk itu dialihkan penanaman pada musim tanaman dari palawija menjadi bera.

3. Selain itu kekurangan air juga disebabkan oleh adanya air di bendungan yang masuk ke kolamkolam ikan masyarakat setempat yang ada di sekitar bendung Kaiti.

Salah satu cara untuk meningkatkan hasil pertanian di DI Kaiti Samo adalah dengan cara menggunakan pengaturan cara pemberian air irigasi yang baik dan juga pengaturan pola tanam rencana yang lebih optimal sesuai kondsi lapangan.

Tujuan dilakukan penelitian ini untuk menganalisis sistem pembagian dan pemberian air irigasi di Daerah Irigasi (DI) Kaiti Samo berdasarkan pola tanam Padi-Padi-Padi. Manfaat penelitian ini sebagai bahan informasi bagi masyarakat Kaiti Samo khususnya dan masyarakat luas pada umumnya dalam upaya untuk pemanfaatan kebutuhan air irigasi serta luas lahan optimal yang dapat dimanfaatkan untuk pertanian.

\section{TINJAUAN PUSTAKA}

\section{Evapotranspirasi}

Evapotranspirasi disebut juga kebutuhan konsumtif tanaman. Faktor-faktor yang mempengaruhi kebutuhan konsumtif tanaman adalah kecepatan angin, penyinaran matahari, kelembaban udara, temperatur suhu. Rumus penman modifikasi untuk mengitung evapotranspirasi potensial adalah :

$$
E_{t o}=c \times(W \times R n+(1-w) \times f(u) \times(e a-e d))
$$

Keterangan :

$$
\begin{array}{ll}
\text { ea } & =\text { Tekanan uap jenuh }(\text { mbar }) \\
\text { ed } & =\text { Tekanan uap nyata }(\text { mbar }) \\
\mathrm{f}(\mathrm{U}) & =\text { Fungsi angin }(\mathrm{m} / \mathrm{s}) \\
\mathrm{U} & =\text { Kecepatan angin }(\mathrm{m} / \mathrm{s}) \\
1-\mathrm{W} & =\text { Faktor pembobot } \\
\mathrm{Rn} & =\text { Rns }- \text { Rnl } \\
\mathrm{Rns} & =\text { Radiasi gelombang pendek netto } \\
\mathrm{Rnl} & =\text { Radiasi gelombang panjang netto } \\
\mathrm{C} & =\text { Koefisien bulanan }
\end{array}
$$

\section{Curah Hujan Efektif}

Curah hujan efektif digunakan untuk memenuhi air konsumtif tanaman . Besarnya curah hujan ditentukan dengan $70 \%$ dari curah hujan rata rata tengah bulanan dengan kemungkinan kegagalan $20 \%$ menggunakan Basic Year dengan rumus [2]:

Tanaman padi :

$$
\mathrm{Re}=\frac{1}{15} x 70 \% \times R_{80}
$$

Tanaman Palawija :

$$
\operatorname{Re}=\frac{1}{15} \times 70 \% \times R_{50}
$$

Keterangan :

$\mathrm{Re}=$ Curah hujan efektif $(\mathrm{mm})$

$\mathrm{R}_{80}=$ Curah hujan probabilitas $80 \%(\mathrm{~mm})$

$\mathrm{R}_{50}=$ Curah hujan probabilitas $50 \%(\mathrm{~mm})$

\section{Kebutuhan Air Irigasi}

Kebutuhan air irigasi merupakan jumlah air yang dibutuhkan untuk memenuhi kebutuhan kehilangan air, evaporasi, kebutuhan air untuk tanaman dengan jumlah air yang diberikan melalui hujan dan air tanah [5]. Kebutuhan air irigasi dapat dihitung dengan langkah-langkah berikut :

1. Menghitung nilai evapotranspirasi potensial.

$$
E t c=K c \times E t o
$$

2. Menghitung konsumtif tanaman

3. Memperkirakan nilai laju perkolasi lahan yang dipakai sesuai kondisi lapangan.

4. Memperkirakan Pergantian lapisan air

5. Menghitung kebutuhan air untuk penyiapan

$$
I R=\frac{M e^{k}}{\left(e^{k}-1\right)}
$$

6. Menghitung curah hujan efektif

7. Menghitung kebutuhan air disawah (NFR)

Padi $\quad: N F R=E t c+P-\operatorname{Re}+W L R$ 
Palawija : $N F R=E t c-\operatorname{Re}$

8. Menghitung tingkat efesiensi saluran irigasi Eff $=$ Eff primer $x$ Eff sekunder $x$ Eff tersier 9. Menghitung kebutuhan air pada pintu pengambilan

$$
D R=N F R \times A / E f f
$$

\section{Debit Andalan Metode Regional}

Debit andalan adalah besarnya debit yang tersedia di sumber air yang dimanfaatkan sebagai penyediaan air dengan resiko kegagalan yang telah diperhitungkan. Bilamana tidak tersedia data debit pada setiap titik simpul atau node dari sistem tata air maka untuk perhitungan besarnya debit yang tersedia di masing-masing titik simpul, dapat dilakukan dengan menggunakan metode regional.

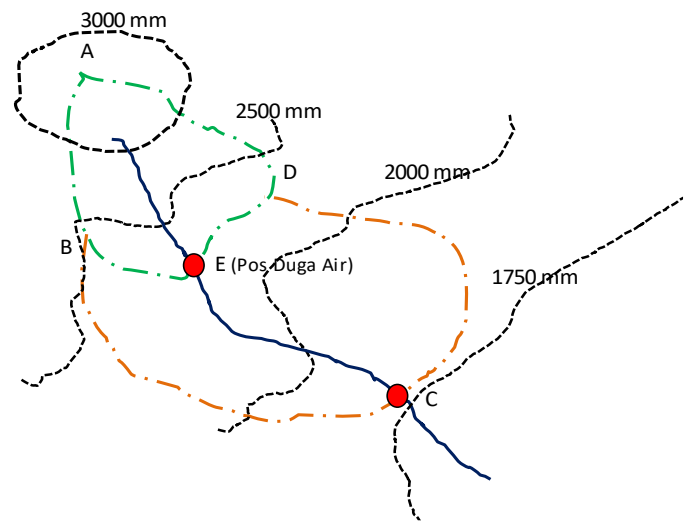

Gambar 1. Konsep Metode Regional

Persamaan yang digunakan pada Gambar 1 pada metode regional sebagai berikut:

$$
Q_{E C}=\frac{C A_{E C}}{C A_{P D A}} \times \frac{M A R_{E C}}{M A R_{P D A}} \times Q_{P D A}
$$

Keterangan :

QEC = Debit pada Sub-DAS yang akan dihitung (DAS antara titik E dan C)

$\mathrm{CA}_{\mathrm{Ec}}=$ Luas catchment area Sub-DAS yang akan dihitung

MAR $_{\mathrm{EC}}=$ Curah hujan rata-rata tahunan didaerah Sub-DAS yang akan dihitung

QPDA = Debit bulanan pada lokasi pos duga air

$\mathrm{CA}_{\mathrm{PDA}}=$ Luas catchment area pada lokasi pos duga air

MAR $_{\text {PDA }}=$ Curah hujan rata-rata tahunan di catchment area pos duga air

Tot $\mathrm{Q}_{\mathrm{c}} \quad=$ Debit pada titik $\mathrm{C}$

\section{Debit Andalan Metode Weilbull}

Debit andalan dihitung berdasarkan probabilitas $80 \%$ dari debit inflow sumber air pada pencatatan debit dan periode tertentu. Untuk mengetahui besarnya nilai debit andalan dengan probabilitas $80 \%$ digunakan Metode Weibull. Rumus weibull untuk menghitung debit andalan :

$$
P=\frac{m}{n+1} \times 100 \%
$$

Keterangan:

$\mathrm{P}=$ Probabilitas terjadinya kumpulan nilai (misalnya: debit) yang diharapkan selama periode pengamatan $(\%)$

$\mathrm{m}=$ Nomor urut kejadian

$\mathrm{n} \quad=$ Jumlah data debit

\section{Sistem Pemberian Air Irigasi}

Sistem Pemberian Air Irigasi dapat dilakukan dengan lima cara [3] yaitu:

1. Penggenangan ( flooding)

2. Menggunakan alur besar atau kecil

3. Menggunakan air di bawah permukaan tanah melalui sub irigasi

4. Penyiraman (sprinkling)

5. Menggunakan sistem cucuran (trickle)

\section{Cara Pembagian Air Irigasi}

Cara pembagian air irigasi ada tiga cara yaitu: sistem serentak, sistem golongan dan sistem rotasi. Penerapan ketiga cara tersebut tergantung pada jumlah air yang tersedia.

\section{Sistem Serentak}

Sistem serentak pembagian air irigasi dilakukan jika jumlah air yang tersedia cukup banyak untuk memenuhi kebutuhan air tanaman yang dinyatakan dengan nilai $\mathrm{k}$ lebih besar atau sama dengan satu. Pembagian air dilakukan secara bersamaan keseluruh areal yang ditanami.

\section{Sistem Golongan}

Pemberian air dengan sistem golongan dapat mengurangi kebutuhan puncak air irigasi [1]. Pada musim kemarau keadaan air mengalami penurunan atau kritis, maka pemberian air tanaman akan diberikan kepada tanaman yang telah direncanakan. Cara ini dilakukan apabila jumlah air yang tersedia cukup terbatas, sementara kebutuhan air sangat besar. Idealnya satu daerah irigasi dibagi menjadi tiga sampai lima golongan dengan jarak waktu tanam dua sampai tiga minggu.

\section{Sistem Rotasi}

Metode rotasi irigasi adalah apabila kebutuhan air irigasinya besar sementara air yang tersedia kurang, maka perlu dilakukan pemberian air secara sistem rotasi atau bergilir. Idealnya waktu giliran dua sampai tiga hari dan tidak boleh lebih dari 
satu minggu karena akan berpengaruh terhadap per tumbuhan tanaman [2]. Cara pemberian air di saluran tersier atau saluran utama dengan interval waktu tertentu bila debit yang tersedia kurang dari faktor K. Jika persediaan air cukup maka faktor K sama dengan satu $(\mathrm{K}=1)$ pembagian dan pemberian air sama dengan rencana pembagian dan pemberian air sedangkan pada persediaan air kurang maka faktor $\mathrm{K}$ kecil dari satu $(\mathrm{K}<1)$ cara pemberian air lebih ditekankan pada pemenuhan kebutuhan air irigasi untuk beberapa petak. Rumus untuk menghitung faktor K [4] :

$$
K=\frac{\text { debit ters edia diintake }}{\text { debit yang dibutuhkan }}
$$

\section{Neraca Air}

Neraca air (water balance) dihitung berdasarkan perbandingan debit aktual dan kebutuhan air irigasi [1]. Jika debit melimpah maka kebutuhan dipenuhi sesuai luas sawah maksimum. Jika debit kurang, maka ada tiga alternatif yaitu:

1. Luas lahan daerah irigasi dikurangi

2. Melakukan modifikasi dalam pola tanam rencana

3. Pemberian air dengan rotasi teknis

\section{METODE PENELITIAN}

\section{Lokasi Penelitian}

Lokasi penelitian berada di wilayah Kabupaten Rokan Hulu DI Kaiti Samo tepatnya di Desa Kaiti sampai Desa Batang Samo, Kecamatan Rambah Samo. DI Kaiti Samo memiliki luas potensial 1.594 ha dengan luas chatchment area $33,72 \mathrm{~km}^{2}$. Lokasi penelitian dapat dilihat pada Gambar 2 .

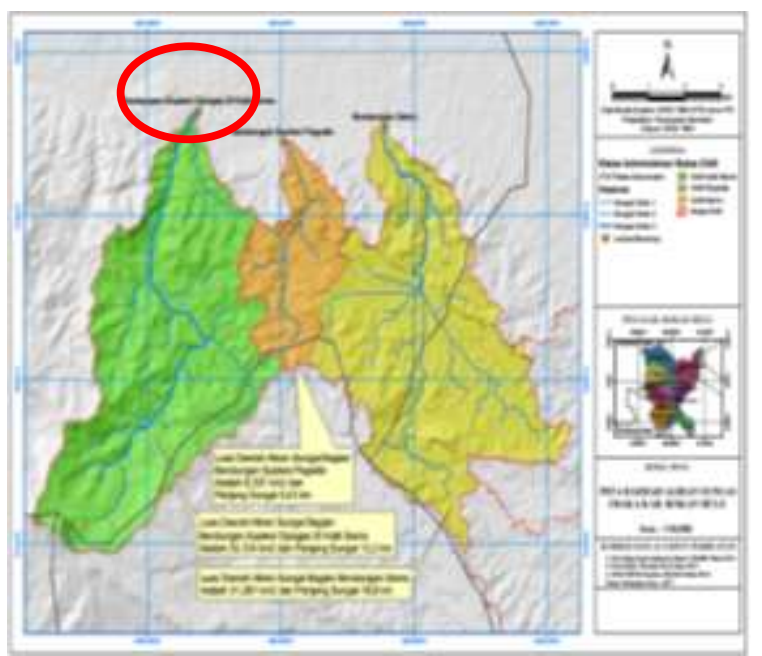

Gambar 2. Lokasi Penelitian

\section{Daerah Aliran Sungai}

Dalam sistem DI Kaiti terdapat koneksi antara beberapa bendung meliputi Bendung Kaiti, Bendung Pegadis dan Bendung Samo. Ketiga bendung tersebut merupakan suatu Daerah Aliran Sungai yang saling berdekatan bukan merupakan satu aliran sungai. Berdasarkan Gambar 2 di Sungai Kaiti ini terdapat Bendung Kaiti dengan luas tangkapan air hujan (Catchment Area) sekitar 33,72 $\mathrm{Km}^{2}$ dengan luas areal genangan sekitar $7 \mathrm{Ha}$. Panjang sungai utama Sungai Kaiti ini sekitar 24,26 km, sedangkan panjang sungai utama hingga ke site bendung 12,2 km. Bendung Kaiti ini berjarak sekitar $6,5 \mathrm{~km}$ dari kota Pasir Pengaraian. Bendung Pegadis merupakan bagian dari sistem DAS Pegadis dengan luas DAS (oulet bendung Pegadis) adalah $8,54 \mathrm{~km}^{2}$ dengan panjang sungai $5,43 \mathrm{~km}$. Sedangkan bendung Samo merupakan bagian dari sistem DAS Samo dengan luas DAS 31,28 $\mathrm{Km}^{2}$ dengan panjang sungai 10,80 $\mathrm{km}$.

\section{Diagram Alir Penelitian}

Pelaksanaan penelitian ini terdiri dari beberapa proses tahapan dan untuk lebih jelasnya dapat dilihat pada Gambar 3. Adapun tahapan penelitian yaitu:

1) Melakukan studi literatur yaitu pencarian materi yang berikatan dan berhubungan dengan topik tugas akhir sebagai referensi penulis

2) Melakukan pengumpulan data yang akan digunakan dalam perhitungan. Data yang dikumpulkan yaitu :

a. Data Curah Hujan

b. Data Klimatologi

c. Data Luas DI

d. Skema Jaringan Irigasi

e. Data Jenis Tanaman

f. Data AWLR

3) Menghitung debit andalan dan melakukan analisis kebutuhan air irigasi

4) Melakukan evaluasi pola tanam rencana

5) Menganalisis Neraca air

6) Berdasarkan neraca air dapat dilihat ketersediaan air irigasi. Jika ketersedian air lebih besar dari kebutuhan air maka mendapatkan hasil persen kebutuhan air, jika tidak maka dilakukan penganturan jadwal dan pemberian air irigasi menggunakan sistem rotasi. Pada penelitian ini penjadwalan rotasi mengggunakam periode gilir 15 harian selama 24 jam. Persamaan yang digunakan jika rotasi menggunakan 2 golongan yang dibuka yaitu :

a. Blok I ditutup, Blok II dan III dibuka

$$
=\frac{(\text { Kebutuhan Blok II }+ \text { Kebutuhan Blok III }) / 2}{\text { Total Kebutuhan air }} \times 360
$$


b. Blok II ditutup, Blok I dan III dibuka

$$
=\frac{(\text { Kebutuhan Blok I }+ \text { Kebutuhan Blok III }) / 2}{\text { Total Kebutuhan air }} \times 360(14)
$$

\begin{tabular}{lc} 
Januari & 4,18 \\
Februari & 4,61 \\
Maret & 4,26 \\
April & 3,69 \\
Mei & 3,72 \\
\hline \multicolumn{1}{c}{ Bulan } & Evapotranspirasi \\
\hline Juni & 3,69 \\
Juli & 3,60 \\
Agustus & 4,42 \\
September & 4,37 \\
Oktober & 4,56 \\
November & 4,25 \\
Desember & 4,27 \\
\hline
\end{tabular}

. Blok III ditutup, Blok I dan II dibuka $=\frac{(\text { Kebutuhan Blok I }+ \text { Kebutuhan Blok II }) / 2}{\text { Total Kebutuhan air }} \times 360(15)$

\section{7). Proses selesai}

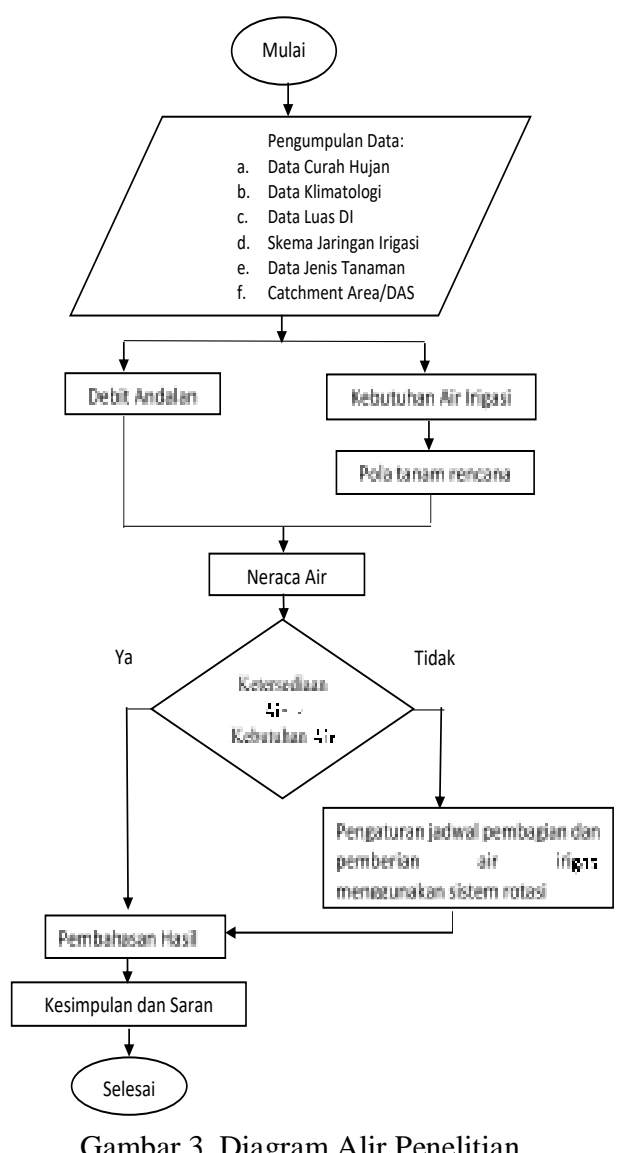

\section{HASIL DAN PEMBAHASAN}

\section{Evapotranspirasi}

Perhitungan evapotranspirasi potensial (ETo) menggunakan Persamaan (1). Hasil perhitungan evapotranspirasi potensial (ETo) menggunakan Metode Penman Modifikasi pada Tabel 1 .

Tabel 1. Perhitungan evapotranspirasi

$$
\text { Bulan Evapotranspirasi }
$$$$
\text { ( } \mathrm{mm} / \mathrm{hari})
$$

\section{Ketersediaan Air Irigasi}

Analisa ketersedian air DI Kaiti Samo terdiri dari analisis curah hujan efektif dan analisis debit andalan. Analisis ini dilakukan berdasarkan data yang diperoleh dari Stasiun Hujan Rambah Utama mulai dari tahun 2008 hingga 2017.

\section{Curah Hujan Efektif}

Perhitungan curah hujan efektif untuk tanaman padi menggunakan Persamaan (2). Hasil perhitungan curah hujan efektif dapat dilihat Tabel 2.

Tabel 2. Perhitungan curah hujan efektif

\begin{tabular}{ccc}
\hline Bulan & Periode & $\begin{array}{c}\text { Curah Hujan } \\
\text { Efektif } \\
\text { (mm/hari) }\end{array}$ \\
\hline Januari & I & 3,01 \\
Februari & II & 1,51 \\
& I & 2,17 \\
Maret & II & 1,24 \\
& I & 1,42 \\
April & II & 4,94 \\
& I & 3,39 \\
Mei & II & 3,85 \\
& I & 5,20 \\
Juni & II & 1,37 \\
& I & 1,53 \\
Juli & II & 1,17 \\
Agustus & I & 1,53 \\
& II & 1,44 \\
& I & 0,66
\end{tabular}




\begin{tabular}{ccc} 
& II & 2,84 \\
September & I & 1,56 \\
& II & 2,03 \\
Oktober & I & 0,58 \\
& II & 2,17 \\
November & I & 5,34 \\
& II & 3,74 \\
Desember & I & 2,52 \\
& II & 3,24 \\
\hline
\end{tabular}

\section{Debit Andalan}

Analisis debit andalan menggunakan metode regional yaitu pada Persamaan (10). Berikut merupakan hasil perhitungan ketersediaan air Kaiti Samo pada Tabel 3:

\begin{tabular}{|c|c|c|}
\hline Bulan & Periode & $\begin{array}{c}\text { Q80 } \\
\text { (m3/det) }\end{array}$ \\
\hline \multirow{2}{*}{ Januari } & I & 2,92 \\
\hline & II & 3,54 \\
\hline \multirow{2}{*}{ Februari } & I & 2,63 \\
\hline & II & 2,78 \\
\hline \multirow{2}{*}{ Maret } & I & 2,65 \\
\hline & II & 3,44 \\
\hline \multirow{2}{*}{ April } & I & 3,23 \\
\hline & II & 3,49 \\
\hline \multirow{2}{*}{ Mei } & I & 2,49 \\
\hline & II & 1,94 \\
\hline \multirow{2}{*}{ Juni } & I & 1,66 \\
\hline & II & 1,46 \\
\hline \multirow{2}{*}{ Juli } & I & 1,81 \\
\hline & II & 1,42 \\
\hline \multirow{2}{*}{ Agustus } & I & 1,14 \\
\hline & II & 1,88 \\
\hline \multirow{2}{*}{ September } & I & 1,93 \\
\hline & II & 1,83 \\
\hline \multirow{2}{*}{ Oktober } & I & 1,81 \\
\hline & II & 1,55 \\
\hline \multirow{2}{*}{ November } & I & 3,09 \\
\hline & II & 3,75 \\
\hline \multirow{2}{*}{ Desember } & I & 2,87 \\
\hline & II & 3,71 \\
\hline
\end{tabular}

\section{Pembagian Blok}

Pemilihan golongan atau blok ini tergantung pada kondisi lapangan yaitu:

a. Kesiapan petugas lapangan yang melaksanakan kegiatan operasi jaringan irigasi

b. Kedisiplinan P3A terhadap rencana tata tanam

c. Kondisi bangunan jaringan irigasi d. Kebutuhan air irigasi oleh tanaman kebutuhan air irigasi oleh tanaman dihitung berdasarkan luas tanaman dan kebutuhan air irigasi per satuan luas tanaman.

e. Ketersediaan Air Irigasi

Pembagian air secara golongan di jaringan tersier dilaksanakan oleh petani, juru dan P3A. Menggilirkan pembagian air diantara blok-blok kwarter didalam petak tersier dengan cara menutup dan membuka pintu ke saluran-saluran sub tersier atau kwarter selama waktu tertentu. Perencanaan pintu air pada sistem golongan atau pembagian blok dibagi 3 blok dilakukan dengan cara dua pintu air dibuka dan satu pintu air ditutup sesuai dengan waktu pembagian rotasi

\section{Kebutuhan Air Irigasi}

Kebutuhan air pada irigasi digolongkan menjadi 3 golongan untuk mengatasi kekurangan air yang terjadi ketika perhitungan kebutuhan air langsung diberikan untuk tiap petak sawah tanpa penggolongan terlebih dahulu. Analisis kebutuhan air irigasi dilakukan dalam pola tanam padi-padi-padi dengan awal tanam September periode I, Oktober periode I, dan November periode I. Tabel 4 merupakan hasil rekapitulasi kebutuhan air irigasi :

Tabel 4. Rekapitulasi kebutuhan air pola tanam padipadi-padi

\begin{tabular}{|c|c|c|c|c|c|c|c|c|c|c|c|c|c|}
\hline \multirow{2}{*}{ DI } & \multirow{2}{*}{ BLOK } & \multicolumn{2}{|c|}{ Sep } & \multicolumn{2}{|c|}{ Okt } & \multicolumn{2}{|c|}{ Nov } & \multicolumn{2}{|c|}{ Des } & \multicolumn{2}{|c|}{ Jan } & \multicolumn{2}{|c|}{ Feb } \\
\hline & & I & II & I & II & I & II & I & II & I & II & I & II \\
\hline \multirow{3}{*}{ Kaiti Samo } & I & 1,41 & 1,36 & 0,93 & 0,74 & 0,32 & 0,48 & 0,17 & 0,00 & 1,04 & 1,22 & 0,76 & 0,85 \\
\hline & II & 0 & 0,00 & 1,60 & 1,41 & 0,36 & 0,54 & 0,67 & 0,56 & 0,12 & 0,06 & 1,22 & 1,33 \\
\hline & III & & 0,30 & 0,18 & 0,00 & 0,41 & 0,49 & 0,29 & 0,25 & 0,25 & 0,31 & 0,10 & 0,04 \\
\hline \multicolumn{2}{|c|}{ Jumlah } & 2,04 & 1,65 & 2,71 & 2,14 & 1,09 & 1,51 & 1,13 & 0,81 & 1,41 & 1,59 & 2,08 & 2,22 \\
\hline
\end{tabular}

\begin{tabular}{|c|c|c|c|c|c|c|c|c|c|c|c|c|c|}
\hline \multirow{2}{*}{ DI } & \multirow[b]{2}{*}{ Blok } & \multicolumn{2}{|c|}{ Mar } & \multicolumn{2}{|c|}{ Apr } & \multicolumn{2}{|c|}{ Mei } & \multicolumn{2}{|c|}{ Jun } & \multicolumn{2}{|c|}{ Jul } & \multicolumn{2}{|c|}{ Ags } \\
\hline & & 1 & II & 1 & II & 1 & II & 1 & II & I & 11 & I & II \\
\hline \multirow{3}{*}{ Kaiti Samo } & I & 0,77 & 0,34 & & 0,00 & 75 & 1,20 & 71 & 4 & 68 & 0 & 40 & 0,00 \\
\hline & II & 0,83 & 0 & 0, & 0,42 & 0,00 & $0, \mathrm{c}$ & 1,22 & 7 & 0,73 & 0,73 & 91 & 0,63 \\
\hline & 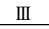 & 0,5 & 0,35 & 0,2 & 0,19 & 0,12 & 0,30 & 0, & 4 &, 50 & 0, & 39 & 0,28 \\
\hline Jumla & & 2,13 & 1,09 & 0,75 & 0,60 & 0,87 & 1,57 & 2,05 & 2,05 & 1,91 & 1,90 & 1,70 & 0,9 \\
\hline
\end{tabular}

\section{Neraca Air}

Imbangan air dilakukan pada luasan eksisting dan luasan golongan. Kondisi eksisting adalah luasan nyata pada daerah irigasi sedangkan kondisi golongan adalah luasan setelah dilakukan pembagian golongan. Jika hasil imbang air bernilai negatif, maka kondisi periode tersebut dikatakan sebagai defisit atau kekurangan air dan apabila bernilai positif maka dikatakan dalam konisi surplus atau kelebihan air. Tabel 5 dan Tabel 6 adalah hasil neraca air pada kondisi eksisting dan golongan: 
Tabel 5. Perhitungan neraca air kondisi eksisting

\begin{tabular}{|c|c|c|c|c|c|c|c|c|}
\hline Bulan & Periode & MT & $\begin{array}{c}\text { Kebutuhan } \\
\mathrm{m} 3 / \mathrm{dt}\end{array}$ & $\begin{array}{c}\text { Ketersediaan Air } 0 \\
\text { Andalan } 80 \% \\
\text { m3/dt }\end{array}$ & Imbang Air & Kondisi & Faktor K & $\begin{array}{l}\text { Rata-rata } \\
\text { Faktor K }\end{array}$ \\
\hline \multirow{2}{*}{ September } & 1 & \multirow{8}{*}{ I } & 3,48 & 1,93 & $-1,56$ & Defisit & 0,55 & \multirow{8}{*}{0,84} \\
\hline & 2 & & 3,35 & 1,83 & $-1,51$ & Defisit & 0,55 & \\
\hline \multirow{2}{*}{ Oktober } & 1 & & 2,30 & 1,81 & $-0,49$ & Defisit & 0,79 & \\
\hline & 2 & & 1,82 & 1,55 & $-0,26$ & Defisit & 0,85 & \\
\hline \multirow{2}{*}{ November } & 1 & & 0,79 & 3,09 & 2,30 & Surplus & 1,00 & \\
\hline & 2 & & 1,18 & 3,75 & 2,57 & Surplus & 1,00 & \\
\hline \multirow{2}{*}{ Desember } & 1 & & 0,43 & 2,87 & 2,44 & Surplus & 1,00 & \\
\hline & 2 & & 0,00 & 3,71 & 3,71 & Surplus & 1,00 & \\
\hline \multirow{2}{*}{ Januari } & 1 & \multirow{8}{*}{ II } & 2,58 & 2,92 & 0,34 & Surplus & 1,00 & \multirow{8}{*}{1,00} \\
\hline & 2 & & 3,00 & 3,54 & 0,54 & Surplus & 1,00 & \\
\hline \multirow{2}{*}{ Februari } & 1 & & 1,87 & 2,63 & 0,76 & Surplus & 1,00 & \\
\hline & 2 & & 2,10 & 2,78 & 0,68 & Surplus & 1,00 & \\
\hline \multirow{2}{*}{ Maret } & 1 & & 1,91 & 2,65 & 0,74 & Surplus & 1,00 & \\
\hline & 2 & & 0,84 & 3,44 & 2,60 & Surplus & 1,00 & \\
\hline \multirow{2}{*}{ April } & 1 & & 0,10 & 3,23 & 3,13 & Surplus & 1,00 & \\
\hline & 2 & & 0,00 & 3,49 & 3,49 & Surplus & 1,00 & \\
\hline \multirow{2}{*}{ Mei } & 1 & \multirow{8}{*}{ III } & 1,86 & 2,49 & 0,63 & Surplus & 1,00 & \multirow{8}{*}{0,91} \\
\hline & 2 & & 2,96 & 1,94 & $-1,02$ & Defisit & 0,66 & \\
\hline \multirow{2}{*}{ Juni } & 1 & & 1,76 & 1,66 & $-0,10$ & Defisit & 0,94 & \\
\hline & 2 & & 1,84 & 1,46 & $-0,38$ & Defisit & 0,80 & \\
\hline \multirow{2}{*}{ Juli } & 1 & & 1,68 & 1,81 & 0,13 & Surplus & 1,00 & \\
\hline & 2 & & 1,65 & 1,42 & $-0,23$ & Defisit & 0,86 & \\
\hline \multirow{2}{*}{ Agustus } & 1 & & 0,98 & 1,14 & 0,16 & Surplus & 1,00 & \\
\hline & 2 & & 0,00 & 1,88 & 1,88 & Surplus & 1,00 & \\
\hline
\end{tabular}

Tabel 6. Perhitungan neraca air kondisi golongan

\begin{tabular}{|c|c|c|c|c|c|c|c|c|}
\hline Bulan & Periode & MT & $\begin{array}{c}\text { Kebutuhan } \\
\text { m3/dt }\end{array}$ & $\begin{array}{c}\text { Ketersediaan Air } 0 \\
\text { Andalan } 80 \% \\
\text { m3/dt }\end{array}$ & Imbang Air & Kondisi & Fakkor K & $\begin{array}{l}\text { Rata-rata } \\
\text { Faktor K }\end{array}$ \\
\hline \multirow{2}{*}{ September } & 1 & \multirow{8}{*}{ I } & 2,04 & 1,93 & $-0,12$ & Defisit & 0,94 & \\
\hline & 2 & & 1,65 & 1,83 & 0,18 & Surplus & 1,00 & \\
\hline \multirow{2}{*}{ Oktober } & 1 & & 2,71 & 1,81 & $-0,90$ & Defisit & 0,67 & \\
\hline & 2 & & 2,14 & 1,55 & $.0,59$ & Defisist & 0,72 & 000 \\
\hline \multirow{2}{*}{ November } & 1 & & 1,09 & 3,09 & 2,00 & Surplus & 1,00 & 0,92 \\
\hline & 2 & & 1,51 & 3,75 & 2,24 & Surplus & 1,00 & \\
\hline \multirow{2}{*}{ Desember } & 1 & & 1,13 & 2,87 & 1,74 & Surplus & 1,00 & \\
\hline & 2 & & 0,81 & 3,71 & 2,90 & Surplus & 1,00 & \\
\hline \multirow{2}{*}{ Januari } & 1 & & 1,41 & 2,92 & 1,51 & Surplus & 1,00 & \\
\hline & 2 & \multirow{7}{*}{ II } & 1,59 & 3,54 & 1,95 & Surplus & 1,00 & \\
\hline \multirow{2}{*}{ Febraari } & 1 & & 2,08 & 2,63 & 0,55 & Surplus & 1,00 & \\
\hline & 2 & & 2,22 & 2,78 & 0,56 & Surplus & 1,00 & 0 \\
\hline \multirow{2}{*}{ Maret } & 1 & & 2,13 & 2,65 & 0,52 & Surplus & 1,00 & , \\
\hline & 2 & & 1,09 & 3,4 & 2,35 & Surplus & 1,00 & \\
\hline \multirow{2}{*}{ April } & 1 & & 0,75 & 3,23 & 2,48 & Surplus & 1,00 & \\
\hline & 2 & & 0,60 & 3,49 & 2,89 & Surplus & 1,00 & \\
\hline \multirow{2}{*}{$\mathrm{Me}$} & 1 & \multirow{8}{*}{$\mathbb{I I}$} & 0,87 & 2,49 & 1,62 & Surplus & 1,00 & \\
\hline & 2 & & 1,57 & 1,94 & 0,37 & Surplus & 1,00 & \\
\hline \multirow{2}{*}{ Juni } & 1 & & 2,05 & 1,66 & $-0,38$ & Defisit & 0,81 & \\
\hline & 2 & & 2,05 & 1,46 & $-0,59$ & Defisit & 0,71 & 6 \\
\hline \multirow[t]{2}{*}{ JII } & 1 & & 1,91 & 1,81 & $-0,11$ & Defisit & 0,94 & 0,00 \\
\hline & 2 & & 1,90 & 1,42 & $-0,48$ & Defisit & 0,75 & \\
\hline \multirow{2}{*}{ Agustus } & 1 & & 1,70 & 1,14 & $-0,56$ & Defisit & 0,67 & \\
\hline & 2 & & 0,90 & 1,88 & 0,98 & Surplus & 1,00 & \\
\hline
\end{tabular}

\section{Jadwal Rotasi}

Penjadwalan dan pembagian rotasi hanya dilakukan untuk musim tanam yang mengalami kekurangan air (defisit) setelah dilakukan penggolongan dan dianalisa menggunakan neraca air. Untuk melakukan penjadwalan rotasi dilapangan harus ada prasananya dimana prasarananya ini sangat penting dalam penjadwalan rotasi yaitu pintu air. Pintu air ini harus mampu bekerja dengan baik yang bisa digunakan untuk menutup dan membuka sehingga dapat mengalirkan sumber air sampai kelahan pertanian.

Penjadwalan rotasi dalam satu siklus bisa dilakukan dalam periode gilir 10 harian dan 15 harian. Pada penelitian ini penjadwalan rotasi mengggunakam periode gilir 15 harian sesuai dengan periode kebutuhan air dan ketersediaan air. Untuk menghitung jadwal rotasi menggunakan Persamaan (13),(14), dan (15). Hasil perhitungan jadwal rotasi seperti pada Tabel 7.

Tabel 7. Jadwal Rotasi Pola Tanam Padi-Padi-Padi

\begin{tabular}{|c|c|c|c|c|c|c|c|c|c|}
\hline \multirow[t]{2}{*}{ Musim Tanam } & Blok & $\begin{array}{r}\text { Kebutuhan } \\
\text { Air (m3/dt) }\end{array}$ & $\begin{array}{l}\text { Total Kebutuhan } \\
\text { Air (m3/dt) }\end{array}$ & \multicolumn{2}{|c|}{$\begin{array}{c}\text { Periode I } \\
\text { Blok I ditutup }\end{array}$} & \multicolumn{2}{|c|}{$\begin{array}{c}\text { Periode II } \\
\text { Blok II ditutup }\end{array}$} & \multicolumn{2}{|c|}{$\begin{array}{l}\text { Periode III } \\
\text { Blok III ditutur }\end{array}$} \\
\hline & I & 5,41 & & 106 & Jam & 105 & Jam & 149 & Jam \\
\hline \multirow[t]{2}{*}{ I } & II & 5,43 & 13,09 & 4 & Hari & 4 & Hari & 6 & Hari \\
\hline & III & 2,25 & & 10 & Jam & 9 & Jam & 5 & Jam \\
\hline \multirow{3}{*}{ III } & I & 5,16 & \multirow{3}{*}{12,96} & 108 & Jam & 103 & Jam & 149 & Jam \\
\hline & II & 5,56 & & 4 & Hari & 4 & Hari & 6 & Har \\
\hline & III & 2,24 & & 12 & Jam & 7 & Jam & 5 & Jam \\
\hline
\end{tabular}




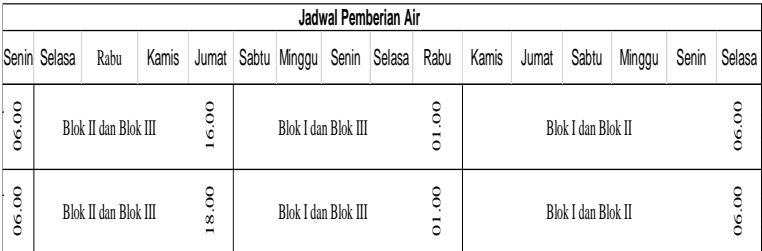

\section{Persentase Pemanfaatan Rotasi dan} Penggolongan Terhadap Debit Ketersediaan

Perhitungan untuk pemanfaatan rotasi terhadap debit tersedia dicari dalam dalam bentuk volume $\left(\mathrm{m}^{3}\right)$ untuk kemudian dibandingkan dan diperoleh persentase kenaikan keberhasilan rotasi dibandingkan dengan penggolongan. Analisis ini dilakukan untuk membuktikan berapa besar persentase sistem rotasi dapat mengurangi defisit pada pola tanam. Nilai masukan yang digunakan pada persentase rotasi dan penggolongan yaitu data kebutuhan dan ketersediaan yang mengalami defisit.

Pada Tabel 6 perhitungan neraca air pola tanam Padi-Padi-Padi untuk DI Kaiti Samo yang tidak tercukupi (defisit) ada 8 periode yaitu pada masa tanam I (MT I) dan masa tanam III (MT III). Tabel 9 adalah hasil perhitungan persetanse sistem rotasi terhadap debit tersedia dan grafik hubungan antara persentase rotasi dan penggolongan terhadap ketersediaan dapat dilihat pada Gambar 4 dan Gambar 5 .

Tabel 8. Persentase volume penggolongan terhadap debit tersedia pola tanam Padi-padi-padi

\begin{tabular}{ccccc}
\hline Musim Tanam & $\begin{array}{c}\text { Kebuthan Penggolongan } \\
\mathrm{m} 3\end{array}$ & $\begin{array}{c}\text { Ketersediaan } \\
\mathrm{m} 3\end{array}$ & $\begin{array}{c}\text { Selish Ketersedian dan } \\
\text { Penggolongan }\end{array}$ & $\begin{array}{c}\text { Persentase Volume Penggolongan } \\
\text { Terhadap Debit Tersedia }\end{array}$ \\
\hline \multirow{3}{*}{ MT I } & 2646193,47 & 2494887,83 & $-151305,64$ & $-6 \%$ \\
& 3509415,41 & 2346429,71 & $-1162985,70$ & $-50 \%$ \\
& 2778896,16 & 2012100,95 & $-766795,20$ & $-38 \%$ \\
\hline \multirow{4}{*}{ MT III } & 2651998,36 & 2154202,57 & $-497795,79$ & $-23 \%$ \\
& 2656658,35 & 1891456,91 & $-765201,43$ & $-40 \%$ \\
& 2477147,94 & 2340660,89 & $-136487,05$ & $-6 \%$ \\
& 2466627,22 & 1841256,57 & $-625370,64$ & $-34 \%$ \\
& 220278,06 & 1473391,63 & $-729396,43$ & $-50 \%$ \\
\hline
\end{tabular}

Tabel 9. Persentase volume rotasi terhadap debit tersedia pola tanam padi-padi-padi

\begin{tabular}{ccccc}
\hline Musim Tanam & Kebutuhan Rotasi $\mathrm{m3}$ & $\begin{array}{c}\text { Ketersedian } \\
\mathrm{m} 3\end{array}$ & $\begin{array}{c}\text { Selish Ketersedian dan } \\
\text { Rotasi }\end{array}$ & $\begin{array}{c}\text { Persentase Volume Rotasi Terhadap } \\
\text { Debit Tersedia }\end{array}$ \\
\hline \multirow{3}{*}{ MT I } & 1818513,91 & 2494887,83 & 676373,92 & $27 \%$ \\
& 2454035,37 & 2346429,71 & $-107605,66$ & $-5 \%$ \\
& 1965358,40 & 2012100,95 & 46742,55 & $2 \%$ \\
\hline \multirow{4}{*}{ MT III } & 1862535,44 & 2154202,57 & 291667,13 & $14 \%$ \\
& 1876765,27 & 1891456,91 & 14691,64 & $1 \%$ \\
& 1673099,27 & 2340660,89 & 667561,62 & $29 \%$ \\
& 1665131,61 & 1841256,57 & 176124,96 & $10 \%$ \\
& 1501608,13 & 1473391,63 & $-28216,50$ & $-2 \%$ \\
\hline
\end{tabular}

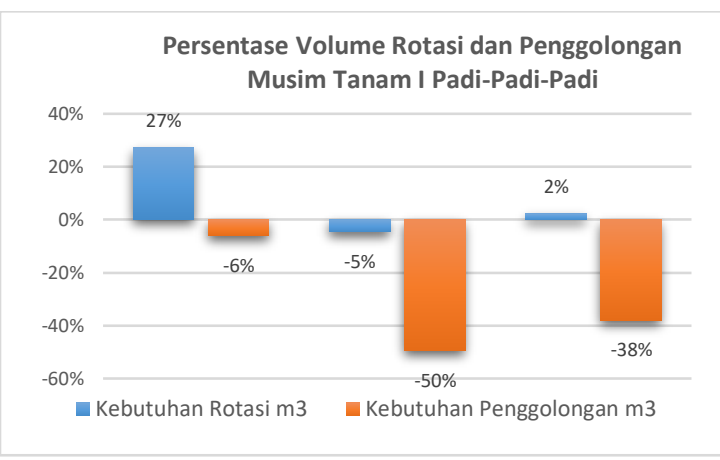

Gambar 4. Grafik Persentase Volume Rotasi dan Penggolongan MT I Padi-Padi-Padi

Pada Gambar 4 dapat di lihat bulan september periode I volume persentase golongan $-6 \%$ setelah di rotasi menjadi $27 \%$, oktober periode I volume persentase golongan $-50 \%$ setelah di rotasi menjasi $-5 \%$, periode II volume persentase golongan $-38 \%$ setelah di rotasi menjadi $2 \%$. Pada sistem golongan masih terjadi defisit dimana ketersediaan air tidak dapat memenuhi kebutuhan air, setelah dilakukan sistem rotasi dapat di lihat bahwa persentasenya meningkat hal ini membuktikan dengan sistem rotasi dapat mengurangi defisit yang masih ada ketika dilakukan penggolongan, tetapi rotasi tidak menghilangkan seluruh kejadian defisit tersebut. Solusi yang dapat digunakan untuk memaksimalkan hasil rotasi yaitu dengan menambah hari penggiliran, mengurangi luas lahan yang akan ditanami, dan merubah varietas (pola tanam).

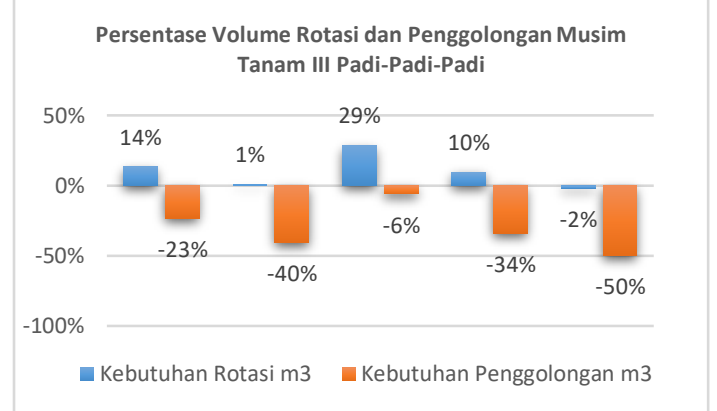

Gambar 5. Grafik Persentase Volume Rotasi dan Penggolongan MT III Padi-Padi-Padi

Pada Gambar 5 dapat di lihat bulan juni periode I volume persentase golongan $-23 \%$ setelah di rotasi menjadi $14 \%$, periode II volume persentase golongan $-40 \%$ setelah di rotasi menjasi $1 \%$, juli periode I volume persentase golongan $-6 \%$ setelah di rotasi menjadi $29 \%$, periode II volume persentase golongan $-34 \%$ setelah di rotasi menjadi $10 \%$, dan agustus periode I volume persentase golongan $-50 \%$ setelah di rotasi menjadi $-2 \%$. Pada sistem golongan masih terjadi defisit dimana ketersediaan air tidak dapat memenuhi kebutuhan air, setelah dilakukan 
sistem rotasi dapat di lihat bahwa persentasenya meningkat hal ini membuktikan dengan sistem rotasi dapat mengurangi defisit.

\section{KESIMPULAN}

Hasil dari besarnya data ketersediaan air periode setengah bulanan, maka besarnya debit andalan $80 \%$ dimana debit terbesar terjadi pada bulan November periode II sebesar $1,72 \mathrm{~m}^{3} /$ det untuk Sungai Kaiti, bulan November periode II sebesar 0,44 $\mathrm{m}^{3} / \mathrm{dt}$ untuk Sungai Pegadis, dan bulan November periode II sebesar $1,60 \mathrm{~m}^{3} /$ det untuk Sungai Samo. Debit terbesar untuk Daerah Irigasi Kaiti Samo pada bulan November periode II sebesar $3,75 \mathrm{~m}^{3} / \mathrm{det}$.

Terjadi kekurangan air defisit terbesar untuk kebutuhan pola tanam Padi-Padi-Padi pada bulan Oktober periode I sebesar 2,71 $\mathrm{m}^{3} / \mathrm{dt}$, dan ketersediaan air sebesar $1,81 \mathrm{~m}^{3} / \mathrm{dt}$.

Berdasarkan nilai neraca air maka dapat diperoleh angka faktor $\mathrm{K}$ yang digunakan dalam pembagian giliran air. Pada kondisi air cukup (surplus) nilai faktor $\mathrm{K}=1$ apabila pada kondisi air tidak tercukupi (defisit) nilai $\mathrm{K}<1$. Untuk pola tanam Padi-Padi-Padi kondisi surplus sebesar 16 periode dan defisit sebesar 8 periode.

Persentase pemanfaatan rotasi dan penggolongan terhadap debit ketersediaan didapatkan hasil bahwa rotasi mengurangi jumlah kejadian defisit yang masih ada ketika dilakukan penggolongan, tetapi rotasi tidak menghilangkan seluruh kejadian defisit tersebut. Solusi yang dapat digunakan untuk memaksimalkan hasil rotasi yaitu dengan menambah hari penggiliran, mengurangi luas lahan yang akan ditanami, dan merubah varietas tanaman.

Kondisi dilapangan Daerah Irigasi Kaiti Samo umumnya banyak yang tidak berfungsi pintu airnya. Penelitian ini dapat dilakukan apabila prasarana berfungsi dengan baik. Jadi penelitian ini dilakukan secara teoritis karena kondisi lapangan yang tidak memenuhi kriteria penjadwalan rotasi.

\section{DAFTAR PUSTAKA}

[1] Departemen Pekerjaan Umum Direktorat Jen. Pengairan, (1986). Standar Perencanaan Irigasi, KP-01 Kriteria Perencanaan Jaringan Irigasi.

[2] Hansen, V. E., Israelsen, O. W., \& Stringham, G. E. (1986). Dasar-dasar dan Praktek Irigasi, (Diterjemahkan oleh E. P. Tachyan). Jakarta: Erlangga.

[3] Hansen, V. E., O.W. Israelsen, dan Stringham, (1992). Dasar-Dasar Praktek Irigasi. Penerbit Erlangga, Jakarta.
[4] Kunaifi, A. A. (2010). Pola Penyediaan Air DI. Tibunangka dengan Sumur Renteng pada Sistem Suplesi Renggung. Tesis tidak dipubikasikan. Malang: Universitas Brawijaya

[5] Sosrodarsono Suyono, (2003). Hidrologi Untuk Pengairan, Pradnya Paramita, Jakarta.

[6] Triatmodjo Bambang, (2008). Hidrologi Terapan, Beta Offset, Yogyakarta. 